\title{
Third-Party Logistics Provider
}

National Cancer Institute

\section{Source}

National Cancer Institute. Third-Party Logistics Provider. NCI Thesaurus. Code C118412.

An entity that coordinates processes involved in the provision of a product or service. 